A LIST OF MARINE SHELLS OCCURRING AT CHRISTMIAS ISLAND, INDIAN OCEAN, WITH DESCRIPTIONS OF NEIV SPECIES.

By E. A. Surtu, I.S.O.

Read 7th April, 1911.

Is these Proceedings (Vol. VIII, pp. 369-72) I gave a list of the shells collected at Christmas Island by Dr. C. W. Andrews on his second risit to that island. A few species obtained by him on his first risit-are now included in the following catalogue, also those enumerated at the above reference. Mr. 1R. Kirkpatrick when at the island last autumn collected nineteen species, of which thirteen were not found bs Dr. Andrews, four of them being undescribed. These were dredged in 30 to 100 fathoms, and doubtless many other interesting new forms remain to be discorered. Dredging operations around the island, however, are very difficult owing to the rocky nature of the bottom.

1. List of Spectes.

1. Glyphis Singaporensis(Reeve). 32. Engina mendicaria (Lamk.).

2. Maliotis, sp. jur.

3. Trochus Niloticus, Linn.

33. Nassa papillosa (Linn.).

4. Turbo Lajonkairii, Desh.

34. N. exulata, n.sp.

5. Nerita grossa, Linn.

35. Columbella varians, var.

6. N. costata, Gmel.

36. Thais armigera (Lamk.).

i. N. polita, Linn.

37. Drupa horrilla (Lamk.).

38. D. clathrata (Lamk.).

8. Plesiotrochus Fischeri, Smith.

9. Truncatella valida, Pfr.

39. D. morns (Lamk.).

40. D. Andreesi (Smith).

10. Amalthea australis (Lamk.).

11. Jitrularia diaphana (Reeve).

12. Cyprea arabica, linn., and var. Gillei, Jousseaume:

13. C. vitellus, Linn.

41. Coralliophila neritoidea, jun.

42. Conus hebraus, Linn., and var. vermiculatus, Lamk.

43. C. minimus, Linn.

14. C. Mauritiana, Tinn.

15. C. lynz $x$ Linn.

16. C. moneta, Linn.

44. Terebra undulata, Grar.

45. Smaragdinella riridis (Rang).

46. Siphonaria ferruginea, Reere.

17. C. annulus, Linn:

47. Arca maculata, Sow.

18. C. poraria, Linn.

48. A. imbricata, Brug.

49. Ai decussata, Sow.

19. Cerithium $\approx e b r a$, var.

20. Triphora triticen, Pease:

21. Planaxis longispira, Smith.

22. Latirus nodatus (Martyn).

50. Brachydontes (Hormomya) mifolineatus, n.sp.

51. Septifer bilocularis (Linn.).

52. S. excisus (Wiegm.).

23. Lencozonia smaragdula(Linn.). 53. Jlelina perna (Linn.).

24. Peristernia nassatula (Lamk.).: 54. Libitina oblonga (Linn.).

25. P. venusta, n.sp.

55. Tellina scobinata, Linn.

26. Jitra fulla, Srainson.

27. Mitra, sp. jur.

28. S. retusa, Lamk.

56. Cardium rubescons, n.sp.

57. Tridacna gigas, jun.

29. II. paupercula, Iamk.

30. Mr. literata, Lamk.

58. Teredo sp.

59. Tylotrya sp.

60. Xylotrya sp.

31. Tritonidea undosa (Linn.).

61. Polypus granulatus (Lamk.). 


\section{Description of New Spectes.}

Peristernia vendsta, n.sp.

Testa minima, breviter fusiformis, albida, ad apicem et antice rosacea, circa medium anfractum linea fusca cincta, infia suturam inter costas roseo maculata; anfractus 7 , duo apicales læres conrexi mammillæ. formi, creteri oblique rotunde costati et spiraliter lirati. lineis incre. menti conspicuis sculpti; anfr. ultimus costis septem infra medium eranescentibus instructus, liris spiralibus circiter undecim (quarto, sexto, et octaro fuscis) ornatus, inter liras spiraliter striatus; apertura parra, antice oblique canaliculata; labrum intus tenuiter lenticulatum ; columella in medio biplicata, rosacea. Long. 7 , diam. $3 \mathrm{~mm}$.; apertura cum canali $3 \mathrm{~mm}$. longa, 1.25 lata.

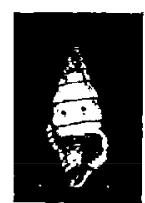

Hab.-Flying Fish Cove, in 45 fathoms. One specimen.

One of the smallest species of the genus and allied to $P$. iniuensis, Melvill, from Sarage Island, Occania. It is, howerer, a little narrower than that species, has more numerous and finer spiral lira, and is also distinguished by the brown thread-like line, which, passing round the body-whorl, revolres up the spire. 'Ihe rosy spots between the upper ends of the costre also constitute a distinguishing feature.

The lines of growth are well marked and sufficiently strong on crossing the spiral lirx to give them a crenulated appearance. The two plica on the columella are, in fact, the continuation of two liro upon the end of the whorl.

Nassa ExULATA, n.sp.

Testa elongata, angusta, acuminata, alba, dilute fusco interrupte balteata; spira clongata, acuminata; anfractus 9 , tres apicales læves, convexi, cæateri minus convexi, sutura profunda sejuncti; anfr. superiores costis obliquis 16-18 instructi, liris tenuibus spiralibus circiter 6 cincti, liris in anfr. anterioribus $2-3$ sensim cranescentibus; anfractus ultimus læris, circa basim striis paucis sculptus, zonis tribus interruptis pallide fuscis ornatus, infra suturam spiraliter striatus, lineis incrementi tenuibus sculptus; apertura parva, oralis, albida; labrum extra incrassatum, album, intus denticulis 9-10 rix conspicuis instructum; columella arcuata, callo albo, superne tenui unidenticulato, antice incrassato, induta. Long. 13 , diam. $5.5 \mathrm{~mm}$.; apertura cum labro $5 \mathrm{~mm}$. longa, intus 2.5 lata.

Hab.-Off Margaret Beaches, in 100 fathoms. One specimen.

A slender form of NTassa with a small aperture and long spire. About three and a half of the upper whorls are prettily sculptured, 
and then the ornamentation berins to die arrar, so that the last and penultimate whorls appear almost smooth to the naked eje, except a few strix round the lower part of the former. 'The colour-markings are pale brown, and consist on the penultimate whorl of two indistinct,

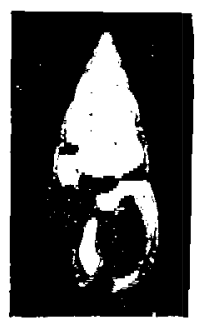

rather interrupted zones, one below the upper suture and the other above the lower suture. These tro bands are continued on the bodywhorl, and there is a third around the base. As in many species, the upper margin of the whorls is somershat distinctly marked off.

\section{Cardida (Fraguir) robescexs, n.sp.}

Testa parra, tenuis, valde inæquilateralis, .trigono-cordata, antice brevissima, alba, postice producta, leviter acuminata, rubescens, interdum omnino ruhescens, costis radiantibus circiter 38 instructi; costæ supra medium valsarum fere planx, delicate squamulato, longe latiores quam sulcis separantibus; costo anteriores et posteriores angustiores, fortius squamos $x$, magis prominentes, sulcis latioribus profundioribus transrersim sculptis separatr; ralra tenues, ad marginem ventralem leviter denticulatæ, postice fortiter dentate; pagina interna antice alba, postice rubescens rel undique rubescens, radiatim sulcata. Long. 8 , alt. 6.5 , diam. $5.5 \mathrm{~mm}$.

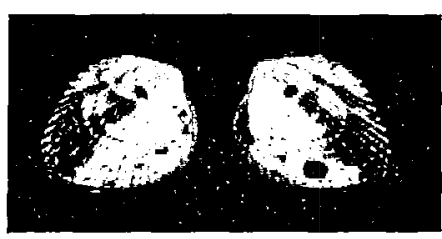

Hab.-Flying Fish Core, in 30 fathoms.

Alliet to $C$. crenelloides, Melvill, and carditeformis, Reere, both Indian Ocean species; there are differences, howerer, of form, colour, and sculpture, which distinguish these three one from the other. C. carditaformis is longer, the ribs are finer and more numerous, and the colour different. C. crenelloides is narrower in front, and less acuminate behind, has more ribs, and is deroid of colour.

Two specimens were obtained by Mr. Kirkpatrick, one entirely rossred, the other with the front half of the ralves almost white, and the 
hincer portion stained with rosaceous, the colour in two more or less sufinsed rays. The radiating riblets upon the middle of the valves are very faintly convex, and scparatod by mere immessed lines. These become more distinct grooves both anteriorly and belind. The lines of growth are distinet in the grooves, and in the impressed strip produce an almost panctate appearance.

\section{Brachydontes (HoRnonya) htrolineatos, a.sp.}

Testa elongata, radiatim et concentrice lirata, wnäique granulata, poriostraco hirsuto induta, sordide abida, postice rufo raculata ef Ineata; margo cardinalis supra ligamentum brevis, rectus, postice rix angulatus; margo ventralis leviter incurvatus; valire tenues, ad marginen intus denticulate, iridescentes, rufo lineata et variegate; margo cardinis ante liganentum dentibus tribus ralidis, quatuor minoribas posticis instructius; umbones palidi, nitentes, concentrice striati, had radiation scupti. Long. $10 \cdot 5$, alt. $5 \cdot 5$, diam. $5.3 \mathrm{~mm}$.

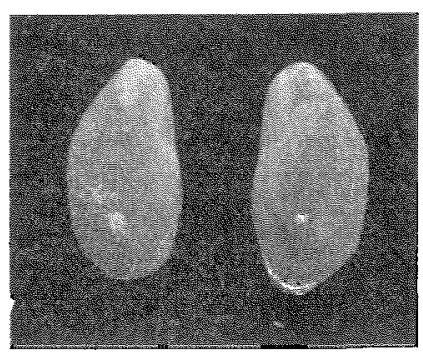

Mab.-Flying Fish Cove, in 30 fathoms.

Allied to Brachydontes (Hormomya) Karachionsis, Molvill \& Standen, but different in form, owing to the shorter hingo-line and the less marked dorsal angle. The concentric sculpture in the prosent spocies is also stronger, causing the radinting lirw to be more grannlous. The colour-markings constitute another distinguishing feature, and the periostracum in Faruchensis appears to be of a less hairy nature.

The margin of the valves is most strongly denticulate along the dorsal tind hinder edges, and somewhat more friely on the rentral side, excepting at the byssal opening, which is smoota. 